\title{
Assessment of DNA damage in a group of professional dancers during a 10-month dancing season
}

Filipa Esteves, Eduardo Teixeira, Tânia Amorim, Carla Costa, Cristiana Pereira, Sónia Fraga, Vanessa Moraes De Andrade, João Paulo Teixeira \& Solange Costa

To cite this article: Filipa Esteves, Eduardo Teixeira, Tânia Amorim, Carla Costa, Cristiana Pereira, Sónia Fraga, Vanessa Moraes De Andrade, João Paulo Teixeira \& Solange Costa (2017) Assessment of DNA damage in a group of professional dancers during a 10-month dancing season, Journal of Toxicology and Environmental Health, Part A, 80:13-15, 797-804, DOI: 10.1080/15287394.2017.1331599

To link to this article: https://doi.org/10.1080/15287394.2017.1331599

Published online: 11 Jul 2017.

Submit your article to this journal $\widetilde{ }$

Щ Article views: 74

Q View related articles $\asymp$

View Crossmark data \lceil

Citing articles: 1 View citing articles $ک$ 


\title{
Assessment of DNA damage in a group of professional dancers during a 10-month dancing season
}

\author{
Filipa Esteves ${ }^{\mathrm{a}, \mathrm{c}}$, Eduardo Teixeiraa ${ }^{\mathrm{b}}$, Tânia Amorim ${ }^{\mathrm{b}}$, Carla Costa ${ }^{\mathrm{a}, \mathrm{c}}$, Cristiana Pereiraa $^{\mathrm{a}, \mathrm{c}}$, Sónia Fraga ${ }^{\mathrm{a}, \mathrm{c}}$, \\ Vanessa Moraes De Andrade ${ }^{d}$, João Paulo Teixeira ${ }^{a, c}$, and Solange Costa ${ }^{a, c}$

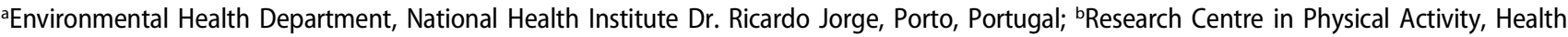

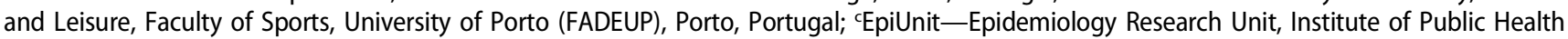 \\ (ISPUP), Porto University, Porto, Portugal; dLaboratory of Molecular and Cellular Biology Graduate Programme of Health Sciences, Health \\ Sciences Unit, University of Southern Santa Catarina, UNESC, Criciúma, Brazil
}

\begin{abstract}
Despite the numerous health benefits of physical activity, some studies reported that increased intensity and duration may induce oxidative stress in several cellular components including DNA. The aim of this study was to assess the level of basal DNA damage as well as oxidative DNA damage in a group of professional dancers before and after a 10-month dancing season. A group of individuals from general population was also assessed as a control. The alkaline version of the comet assay was the method selected to measure both basal DNA damage and oxidative stress, since this method quantifies both endpoints. In order to measure oxidative stress, the comet assay was coupled with a lesion-specific endonuclease (formamidopyrimidine glycosylase) to detect oxidized purines. The levels of oxidative DNA damage in dancers were significantly increased after the dancing season. Pre-season levels of oxidative DNA damage were lower in dancers than those obtained from the general population, suggesting an adaptation of antioxidant system in dancers. Results of the present biomonitoring study indicate the need for more effective measures to protect ballet dancers from potentially occupational health risks related to regular intensive physical exercise.
\end{abstract}

\section{Introduction}

Professional dancing is an activity with high artistic and physical demand and only few apprentices attain professional status. Recent data from Portugal indicate that only $17 \%$ of the students registered in dance degree concluded their graduation (INE (Statistics Portugal), 2015). Dancers are expected to display a repertoire of attributes such as motor coordination, agility, speed, psychological capacity, and strength to perform different types of physical exercises (Russell, 2013). Several studies reported a high incidence of injuries among professional dancers (Allen et al., 2012) most occurring as a result of intense training and lack of appropriate resting periods (Khan et al., 1995; Strassel et al., 2011). Musculoskeletal injuries are the most common health issue noted in professional dancers (Hincapie et al., 2008). The high frequency of injuries and subsequent diminished ability to perform may be related to the severity of muscle damage and oxidative stress (Finaud et al., 2006; Niess \& Simon, 2007).

Despite all benefits associated with regular physical activity such as reduction in health risks including cardiovascular diseases, diabetes, cancer, and osteoporosis as well as promotion of well-being (Hills et al., 2015; Powers \& Jackson, 2008), this process requires increased oxygen uptake to generate byproducts to maintain the physiological responses needed for dancing. However, elevated oxygen uptake may also generate excess production of reactive oxygen species (ROS) (Kurkcu, 2010). Subsequently, the ROS may react with different biomolecules, namely DNA, lipids, and proteins (Birben et al., 2012) inducing oxidative damage that may compromise cell genomic integrity altering many physiological and pathophysiological conditions leading to atherosclerosis (Young \& McEneny, 2001), pulmonary damage (Ghio et al., 2012) cancer (Brieger et al., 2012), and aging (Beckman \& Ames, 1998). 
Although oxidative responses among different sport athletes were reported in several studies (Hadžović-Džuvo et al., 2014 ; Marin et al., 2013; Rowlands et al., 2012), only few studies measured DNA damage (Borges et al., 2014; Orhan et al, 2004). Borges et al. (2014) investigated the effects of a ballet class in 13 ballerinas on DNA fragmentation by flow cytometry and found a significant increase $18 \mathrm{hr}$ after ballet class. Orhan et al. (2004) evaluated the effect of $60 \mathrm{~min}$ on a cycle ergometer in 18 trained males. As a biomarker of oxidative DNA damage, urinary excretion of 8-hydroxy-2'-deoxyguanosine (8-OHdG) was shown to be significantly increased after exercise.

Genotoxicity evaluation is an important tool in human biomonitoring, especially in occupational health enabling identification of potential risk factors. The comet assay or single cell gel electrophoresis (SCGE) is a simple, quick, and sensitive method for quantitatively measuring DNA strand breaks in individual cells. For the last two decades, this method has been extensively employed in biomonitoring studies and in a range of in vivo and in vitro systems (Cemeli \& Anderson, 2011; Dusinska \& Collins, 2008; Ferreira et al., 2016; Trindade et al., 2016). Cells with increased DNA damage display enhanced DNA migration from the nucleus toward the anode (Dusinska \& Collins, 2008). DNA repair glycosylases may also be added to the classic version of comet assay to measure specific DNA lesions, such as oxidized bases. The most commonly used enzyme is formamidopyrimidine glycosylase (FPG) detects oxidized purines, including 8-oxoguanine one of the most common DNA lesions resulting from ROS and an important biomarker of oxidative stress (Danielsen et al., 2008). Thus, incubation with this specific enzyme enables an estimation of the levels of oxidative damage (Azqueta et al., 2009).

Ballet dancers often go beyond their limits due severe competition in Ballet Companies to maintain their positions (Byhring \& Bo, 2002), and consequently, these individuals often overlook injuries (Bowling, 1989). Since there is some evidence that professional dancers are subject to oxidative stress with accompanied DNA damage under acute conditions (Borges et al., 2014; Orhan et al., 2004), it was of interest to determine the consequences of prolonged physical exercise on several genotoxicity biomarkers in a group of ballet dancers. In order to assess the effect of exercise on DNA damage among professional dancers, the alkaline version of the comet assay was employed in a group of professional dancers from a Portuguese Ballet Company to quantify DNA damage and oxidized purines (FPG sensitive-sites) at individual cell level, before and after a 10 -month dancing season.

\section{Material and methods}

\section{Study population}

The general characteristics of the study population are summarized in Table 1. Study population consisted on a total of 28 subjects: 14 professional dancers, which agreed to participate in the study representing $1 / 3$ of the dancers of a Portuguese Ballet Company, performing during the 2014/ 2015 dancing season; and 14 controls, healthy subjects selected from general population with sedentary lifestyle, that is, no regular physical activity. Ballet dancers worked about 10 months having a rest period of only 2 months (mid-July to mid-September). For each subject, relevant individual information such as gender, age, smoking habits, health conditions, and medication was assessed by self-administrated questionnaires. Smoking habits groups were established as nonsmokers and smokers, and 24 were nonsmokers, four (dancers) having stop smoking for at least 2 years, and therefore considered nonsmokers. Professional dancers were also asked regarding the number of years of practice as professional dancers and their training schedule. Dancers had

Table 1. Characteristics of the study population.

\begin{tabular}{|c|c|c|c|c|}
\hline & $N$ & Controls & $N$ & Dancers \\
\hline Gender & 14 & & 14 & \\
\hline Females & & $11(78.6 \%)$ & & $11(78.6 \%)$ \\
\hline Males & & $3(21.4 \%)$ & & $3(21.4 \%)$ \\
\hline Age (years) ${ }^{a}$ & 14 & $\begin{array}{r}39.36 \pm 8.58 \\
(24-57)\end{array}$ & 14 & $\begin{array}{r}32.50 \pm 6.38^{*} \\
(22-42)\end{array}$ \\
\hline Body Mass Index $\left(\mathrm{kg} / \mathrm{m}^{2}\right)^{\text {a }}$ & & $\begin{array}{r}25.23 \pm 4.37 \\
(19-33)\end{array}$ & & $\begin{array}{c}19.30 \pm 2.84 \\
(15-26)\end{array}$ \\
\hline Underweight & & - & & $5(35.7 \%)$ \\
\hline Normal weight & & $9(64.3 \%)$ & & $8(57.1 \%)$ \\
\hline Overweight & & $3(21.4 \%)$ & & $1(7.1 \%)$ \\
\hline Obese & & $2(14.3 \%)$ & & - \\
\hline Years of practice ${ }^{a}$ & & - & & $\begin{array}{c}21.21 \pm 8.21 \\
(2-33)\end{array}$ \\
\hline
\end{tabular}

${ }^{\mathrm{a}}$ Mean \pm SD (standard deviation), (range)

${ }^{*} p<0.05$, significantly different from control group (Student's $t$-test). 
8-hr daily training, at least 5 days per week with an average of about 12 performances per month ( 2 to 3 hours). All subjects were fully informed regarding the procedures and objectives of the study and signed an informed consent form prior to the study. Ethical approval was obtained from the Ethical Board of the National Institute of Health Doutor Ricardo Jorge.

\section{Sample collection}

Venous blood samples $(6 \mathrm{ml})$ were collected in 6ml Vacutainer ${ }^{\circledast}$ EDTA tubes (Becton, Dickinson and Company) by venipuncture from an antecubital vein before and after dancing season. Blood was immediately stored at $4^{\circ} \mathrm{C}$, transported to the lab, and immediately processed for further analysis. All samples were coded and analyzed under blinded conditions and cryopreserved. For cryopreservation, an equal amount of $1: 4(\mathrm{~V} / \mathrm{V})$ mixture of DMSO and RPMI 1640 was added to blood samples. Samples were then stored in aliquots

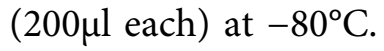

\section{Chemicals (solution composition)}

Dimethyl sulfoxide (DMSO) solution, sodium chloride $(\mathrm{NaCl})$, potassium chloride $(\mathrm{KCl})$, ethanol, and Tris-base were purchased from Merck KGaA, MSD. Fetal bovine serum (FBS), Dulbecco's Modified Eagle Medium (DMEM), normal melting point agarose (NMP), and disodium ethlylenediaminetetraacetate dehydrate (NA2EDTA) were obtained from Thermo Fisher Scientific, Lonza Group AG, VWR Prolabo, and Bioline, respectively. RPMI 1640 solution, phosphate buffered saline (PBS) solution, low-melting point agarose (LMA), tetramethylbutyl)phenylpolyethylene glycol solution (Triton X-100), hydroxyethylpiperazine ethane sulfonic acid (HEPES), and bovine serum albumin (BSA) were purchased from Sigma-Aldrich Company. SYBER ${ }^{\oplus}$ Gold manufactured by Invitrogen ${ }^{\mathrm{Tm}}$ was supplied by Thermo Fisher Scientific.

\section{Alkaline comet assay}

The alkaline comet assay was performed as described by (Singh et al., 1988) with minor modifications (Al-Salmani et al., 2011; Costa et al., 2008). Before the assay whole blood samples were rapidly thawed on ice and washed twice (223g for $10 \mathrm{~min}$ ) with $5 \mathrm{ml}$ DMEM, supplemented with $2 \%$ FBS, $5 \mu$ l sample was dispersed in $0.6 \%$ LMP and dropped into a frosted slide precoated with $1 \%$ NMP. Samples were assessed in duplicate that is two mini-gels per subject. Slides were immersed in cold and freshly prepared lysis solution (2.5 M NaCl, $100 \mathrm{mM} \mathrm{Na}{ }_{2}$ EDTA, $10 \mathrm{mM}$ Tris-base, $0.25 \mathrm{M} \mathrm{NaOH}, \mathrm{pH}$ 10; 1\% Triton X100) for at least $1 \mathrm{hr}$ at $4^{\circ} \mathrm{C}$ in the dark. After this period, slides were submerged in electrophoresis solution ( $1 \mathrm{mM} \mathrm{Na} \mathrm{NDDTA}_{2} 300 \mathrm{mM} \mathrm{NaOH}$ ) for $20 \mathrm{~min}$ at $4^{\circ} \mathrm{C}$, to enable DNA unwinding. Electrophoresis was carried out for $20 \mathrm{~min}$ at $1.2 \mathrm{~V} / \mathrm{cm}$. For neutralization, slides were washed for $10 \mathrm{~min}$ in cold PBS and rinsed for another $10 \mathrm{~min}$ in cold deionized water. Slides were then fixed in $70 \%$ ethanol for $15 \mathrm{~min}$ and in absolute ethanol for further $15 \mathrm{~min}$. Dried slides were stained with SYBER Gold at the dilution recommended by the manufacturer in a bath with agitation for $30 \mathrm{~min}$, rinsed twice with water and left to dry at room temperature. A total of 150 cells per subject ( 75 cells per mini-gel) were scored using the semi-automated image analysis system Comet Assay IV (Perceptive Instruments, UK). Microscopic analyses were performed on a Nikon Eclipse E400 Epi-fluorescence microscope. The percentage of DNA in the comet tail (\%TDNA) was the parameter used to evaluate DNA damage.

\section{Enzyme-comet assay (FPG)}

The modified comet assay was performed as described by Azqueta and Collins (2013). For measurement of oxidized purines, after lysis, slides were washed 3 times ( $5 \mathrm{~min}$ each time) with cold buffer $(0.1 \mathrm{M}$ KCL, $0.5 \mathrm{mM}$ $\mathrm{Na}_{2}$ EDTA, $40 \mathrm{mM}$ HEPES, $0.2 \mathrm{mg} / \mathrm{mL}$ BSA, $\mathrm{pH}$ 8.0) and incubated for $30 \mathrm{~min}$ at $37^{\circ} \mathrm{C}$ with FPG (kindly donated by Prof Andrew R. Collins, University of Oslo, Oslo, Norway) or with buffer alone. The following steps were performed according to the comet assay classical version described above. The percentage of DNA in the comet tail (\%TDNA) was the DNA damage parameter evaluated to describe comet 
formation. Net FPG-sensitive sites, for each subject, were calculated by subtracting the \% TDNA value obtained for buffer and from the value obtained for FPG.

\section{Statistical analysis}

A general description of the study population was performed through univariate analysis. The distribution within the study groups of sociodemographic and lifestyle factors was evaluated with the Student's t-test for continuous variables and the Pearson's chi-square test for categorical variables. Normality was assessed by Shapiro-Wilk test considering the size of the study population $(n=28)$. Both oxidative damage and basal DNA damage departed significantly from normality, and therefore, the analysis of this variable was performed using nonparametric test. To compare the results within each group, a Wilcoxon signed ranks test was used. To compare the variables between groups (comparison between the variation pre- and post-season), a Mann-Whitney test was employed. The influence of factors such as age and years of practice on the endpoints examined was evaluated by nonparametric (Kruskal-Wallis). To test the possible association between variables, a Spearman's rank correlation test was performed. Since four subjects were ex-smokers, the influence of previous smoking habits was also analyzed throught Spearman's rank correlation test; however, no marked effect was found. The level of statistical significance was set at 0.05 . All analyses were performed using the software Statistical Program for Social Sciences-SPSS version 20.0 .

\section{Results}

Table 1 describes the general characteristics of the study population. Dancers and control group were matched for gender; however, no match was found regarding age and BMI. The difference of BMI values between dancers and controls may be justified by the high physical demand and ability to perform certain movements (Koutedakis \& Jamurtas, 2004), and this result is in accordance with several studies on dance nutrition reporting low BMI for dancers compared to general population (Mihajlovic \& Mijatov, 2002; Ribeiro \& Da Veiga, 2010). The low body weight among dancers, particularly ballet professionals, is a concern because it might result in nutritional disorders and other health problems (Abraham, 1996). In our investigation, five dancers were underweight and one was overweight; it should be noted that muscle mass is not included in BMI calculation which may lead to the misclassification of an athlete as overweight (Jonnalagada et al., 2004).

Data from genotoxicity biomarkers in professional dancers before and after the 10 monthseason dancing season are reported in Table 2. Both endpoints were increased after dancing season; however, this difference was only statistically significant with respect to the level of oxidative damage (Net-FPG). A significant inverse association was found for age and DNA damage after season, where the level of DNA damage post-season was higher in younger dancers compared to older dancers. Regarding the years of ballet practice, it was no marked correlation with endpoints which was observed. .

Univariate comparisons between professional dancers (pre-season) and control group (general population) are presented in Table 3. No marked differences were found in the endpoints studied, associated with no significant influence of age, $\mathrm{BMI}$, and gender.

Table 2. Genotoxicity biomarkers measured before and after the season in professional dancers.

\begin{tabular}{|c|c|c|c|c|}
\hline & \multicolumn{4}{|c|}{ Dancers } \\
\hline & \multicolumn{2}{|c|}{ pre-season } & \multicolumn{2}{|c|}{ post-season } \\
\hline & $N$ & mean $\pm \mathrm{SE}$ & $N$ & mean $\pm \mathrm{SE}$ \\
\hline DNA damage & 14 & $6.10 \pm 0.52$ & 14 & $6.55 \pm 0.64$ \\
\hline Net-FPG & 14 & $1.06 \pm 0.16$ & 14 & $4.67 \pm 0.68^{*}$ \\
\hline
\end{tabular}

Table 3. Genotoxicity biomarkers in both studied groups.

\begin{tabular}{lccccc}
\hline & \multicolumn{2}{c}{ Controls } & & \multicolumn{2}{c}{ Dancers (pre-season) } \\
\cline { 2 - 3 } \cline { 5 - 6 } & $N$ & mean \pm SE & & $N$ & mean \pm SE \\
\hline DNA strand breaks & 14 & $5.16 \pm 0.34$ & & 14 & $6.10 \pm 0.52$ \\
Net-FPG & 14 & $2.21 \pm 0.50$ & & 14 & $1.06 \pm 0.16$ \\
\hline
\end{tabular}

SE-Standard Error Deviation. 


\section{Discussion}

Regular intensive physical activity is associated with an increased production of free radicals that may overcome the antioxidant system capacity to maintain homeostasis and lead to cell damage (Fisher-Wellman \& Bloomer, 2009). Dancers are considered both artists and athletes (RodriguesKrause et al., 2014) as a consequence of complex artistic performances that require a high level of athletic skills (Allen et al., 2012).

Our results demonstrated an increase on both levels of genotoxic endpoints after the 10-month dancing season, but only oxidative damage reached statistical significance. The available literature on biomonitoring studies comprising professional dancers is limited, and the evaluation of genotoxic effects encompassing these professionals is even scarcer. Borges et al. (2014) investigated the effect of chronic inflammation and neutrophil activation including neutrophils DNA fragmentation (an apoptosis biomarker) in 13 ballerinas from a ballet class. Blood samples were taken from dancers before, immediately after and $18 \mathrm{hr}$ after class, a significant elevation was found in neutrophils DNA fragmentation $18 \mathrm{hr}$ after class compared to pre-class and immediately after class, illustrating an impact of intense physical exercise on cytogenetic markers after a ballet class.

Dancers are also seen as athletes due to their intense training, some studies investigated the oxidative stress among athletes of different sports, and in accordance with our results, data demonstrated a rise in oxidative stress biomarkers after a period of physical exercise (Chatzinikolaou et al., 2014; Marin et al., 2013; Rowlands et al., 2012). Silva et al. (2013) analyzed biomarkers of oxidative stress (urinary malondialdehyde (MDA) levels) and antioxidant status (activities of glutathione reductase (GR) and superoxide dismutase (SOD) in 14 soccer players during the sport season. A significant increase of oxidative stress biomarkers was noted in the middle and end of the season. However, values return to normal during the off-season. Several studies showed an increased activity of antioxidant system during periods of exercise (Kyparos et al., 2009; Marin et al., 2011). Similar results were also found for athletes (Cash et al., 2014). Marin et al. (2013) examined the effect of a 6-month handball season on oxidative stress (lipidic and amino acid oxidation) and antioxidant system activity biomarkers (SOD, catalase (CAT), glutathione peroxidase (GPx), and (GR) among 10 handball athletes. Results revealed an elevation of oxidative stress parameters during most intense periods but also a significant rise in erythrocyte antioxidant enzyme activity suggesting a training-induced antioxidant adaptation. Data found in the present study also suggest an adaptation of antioxidant system, the pre-season levels of oxidative damage were significantly lower than post-season levels, and although not significant, the pre-season levels were also lower than the level obtained for controls with no regular physical activity.

In the present study, DNA damage seemed to decrease significantly with age among professional dancers, which may be related to lower production of oxidants, up-regulation of antioxidant capacity, or even higher DNA repair activity (Cash et al., 2014; Marin et al., 2013; Soares et al., 2015).

No marked differences were found in the levels of genotoxicity biomarkers between control and preseason professional dancers. Niess et al., (1996) used comet assay to assess the occurrence of DNA damage before and after exhaustive exercise in whole blood of 11 subjects, six well-trained men runners, and five untrained men, physically active but without regular exercise. A significant elevation in DNA migration was noted in both groups only after exercise.

The major confounders, gender and age, did not significantly influence the levels of the endpoints studied. Although the influence of gender on the level of DNA damage remains controversial (Giovannelli et al., 2002; Kasai et al., 2001), Angerer et al. (2007) showed that this is not a factor that affects the damage evaluated by the comet assay. Some investigators examined the influence of age on DNA damage assessed by the comet assay, but with conflicting results (Heuser et al., 2007; Möller, 2006).

The assessment of effect biomarkers such as oxidative and DNA damage in human biomonitoring studies is of paramount importance because of its predictive value and identification of potential genotoxic risk factors (Andersen et al., 2010). Comet assay is a rapid, simple, and relatively economical method that detects DNA damage in individual 
cells (Azqueta et al., 2011), and the possibility of using a specific restriction endonuclease in the comet assay expands the flexibility of the method. Enzymatic version of comet is an important sensitive method for monitoring oxidized DNA bases which may serve as useful markers in multiple diseases including diabetes, rheumatoid, or vascular diseases (Wentzel et al., 2010).

The action of ROS has been widely studied among athletes although there are few investigators that examined the genotoxic effects of sports practice (Niess et al., 1996; Soares et al., 2015). Our findings indicate that the comet assay is a sensitive technique to measure the DNA damage effects resulting from intense physical activity in professional dancers, namely ballet dancers.

To the best of our knowledge, no apparent reports have described the influence of a seasonal period on genotoxicity biomarkers, nor assessed both DNA damage and oxidative damage in professional dancers. Thus, our study constitutes the first examining the genotoxic effects of an entire dancing season in a group of ballet dancers.

However, our study has some limitations including the number of subjects, disproportion number of genders, self-administered questionnaires, and lack of other information regarding lifestyle factors namely diet that may have influenced the endpoints studied. Further studies with larger populations are needed to confirm these results. A study design that combines the measurements of DNA damage, gene expression, and DNA repair mechanisms before, during and after the season, would clarify the mechanisms that maintain DNA stability in response to regular and intensive physical exercise.

\section{Conclusions}

Understanding the role that genotoxic effects play in occupational diseases might improve risk assessment and provide for a better worker health protection through development of prevention methods. Data from our study indicate a significant increase in oxidative damage as a result of a 10 -month period of intense physical activity in professional dancers from a Portuguese Ballet Company, suggesting a potential health risk situation. Moreover, our results demonstrated that comet assay is a useful tool to assess genotoxic effects related to regular intensive exercise. However, these findings need to be carefully interpreted due to the limited population studied. Nevertheless, data found clearly highlight the need of further investigations to elucidate the occupational-health risks related to intense regular physical exercise in this particular group of professionals.

\section{Acknowledgments}

We thank Prof. Andrew R. Collins, University of Oslo, for the kind gift of the FPG enzyme.

\section{Funding}

The work of CC and SC was supported by the Portuguese Foundation for Science and Technology (FCT) under the grants SFRH/BPD/96196/2013 (CC) and SFRH/BPD/ $100948 / 2014$ (SC). The author(s) would like also to acknowledge the contribution of the COST Action CA15132 to the study.

\section{References}

Abraham, S. 1996. Characteristics of eating disorders among young ballet dancers. Psychopathology. 29: 223-229.

Allen, N., Nevill, A., Brooks, J., Koutedakis, Y., and Wyon, M. 2012. Ballet injuries: Injury incidence and severity over 1 year. J. Orthopaedic. Sports. Physical. Ther. 42: 781-A1.

Al-Salmani, K., Hussein, A., Schulpen, S., Karbaschi, M., Abdalla, I., Bowman, K. J., So, K. K., Evans, M. D., Jones, G. D., Godschalk, R. W., and Cooke, M. S. 2011. Simplified method for the collection, storage, and comet assay analysis of DNA damage in whole blood. Free. Radic. Biol. Med.. 51: 719-725.

Andersen, M. E., Al-Zoughool, M., Croteau, M., Westphal, M., and Krewski, D. 2010. The future of toxicity testing. J. Toxicol. Environ. Health. B. 13: 163-196.

Angerer, J., Ewers, U., and Wilhelm, M. 2007. Human biomonitoring: state of the art. Int. J. Hyg. Environ. Health. 210: 201-228.

Azqueta, A. and Collins, A. R. 2013. The essential comet assay: A comprehensive guide to measuring DNA damage and repair. Arch. Toxicol. 87: 949-968.

Azqueta, A., Gutzkow, K. B., Brunborg, G., and Collins, A. R. 2011. Towards a more reliable comet assay: Optimising agarose concentration, unwinding time and electrophoresis conditions. Mutat. Res. 724: 41-45.

Azqueta, A., Shaposhnikov, S., and Collins, A. R. 2009. DNA oxidation: Investigating its key role in environmental mutagenesis with the comet assay. Mutat. Res/Genet. Toxicol. Environ. Mutagen. 674: 101-108. 
Beckman, K. B. and Ames, B. N. 1998. The free radical theory of aging matures. Physiol. Rev. 78: 547-581.

Birben, E., Sahiner, U. M., Sackesen, C., Ezrurum, S., and Kalayci, O. 2012. Oxidative stress and antioxidant defense. World. Allergy. Org. J. 5: 9-19.

Borges, L. S., Bortolon, J. R., Santos, V. C., De Moura, N. R., Dermargos, A., Cury-Boaventura, M. F., Gorjão, R., Pithon-Curi, T. C., and Hatanaka, E. 2014. Chronic inflammation and neutrophil activation as possible causes of joint diseases in ballet dancers. Mediat. Inflammat. 2014: 846021.

Bowling, A. 1989. Injuries to dancers: prevalence, treatment, and perception of causes. Br. Med. J. 298: 731-734.

Brieger, K., Schiavone, S., Miller, J. P., and Krause, K. H. 2012. Reactive oxygen species: From health to disease. Swiss. Med. Weekly. 142: w13659.

Byhring, S. and Bo, K. 2002. Musculoskeletal injuries in the Norwegian National Ballet: A prospective cohort study. Scand. J. Med. Sci. Sports. 6: 365-370.

Cash, S. W., Beresford, S. A., Vaughan, T. L., Heagerty, P. J., Bernstein, L., White, E., and Neuhouser, M. L. 2014. Recent physical activity in relation to DNA damage and repair using the comet assay. J. Physical. Activity. Health. 11: 770.

Cemeli, E. and Anderson, D. 2011. Mechanistic investigation of ROS-induced DNA damage by oestrogenic compounds in lymphocytes and sperm using the comet assay. Int. J. Mol. Sci. 12: 2783-2796.

Chatzinikolaou, A., Draganidis, D., Avloniti, A., Karipidis, A., Jamurtas, A. Z., Skevaki, C. L., Tsoukas, D., Sovatzidis, A., Theodorou, A., Kambas, A., Papassotiriou, I., Taxildaris, K., and Fatouros, I. 2014. The microcycle of inflammation and performance changes after a basketball match. J. Sports. Sci. 32: 870-882.

Costa, S., Coelho, P., Costa, C., Silva, S., Mayan, O., Santos, L. S., Gaspar, J., and Teixeira, J. P. 2008. Genotoxic damage in pathology anatomy laboratory workers exposed to formaldehyde. Toxicology. 252: 40-48.

Danielsen, P. H., Bräuner, E. V., Barregard, L., Sällsten, G., Wallin, M., Olinski, R., Rozalski, R., Møller, P., and Loft, S. 2008. Oxidatively damaged DNA and its repair after experimental exposure to wood smoke in healthy humans. Mutat. Res/Fundam. Mol. Mech. Mutagen. 642: 37-42.

Dusinska, M. and Collins, A. R. 2008. The comet assay in human biomonitoring: Gene-environment interactions. Mutagenesis. 23: 191-205.

Ferreira, N. H., De Andrade, K. J., Leandro, L. F., Acésio, N. A., Mendes, S. A., Cintra, L. S., Januário, A. H., and Tavares, D. C. 2016. Testing of Schefflera vinosa extract in mammalian cells in vitro and in vivo for potential toxicity, genetic damage, and role of oxidation. J. Toxicol. Environ. Health. Part A. 79: 1201-1210.

Finaud, J., Lac, G., and Filaire, E. 2006. Oxidative Stress: Relationship with exercise and training. Sports. Med. 36: 327-358.

Fisher-Wellman, K. and Bloomer, R. J. 2009. Acute exercise and oxidative stress: A 30 year history. Dynamic. Med. 8: 1.
Ghio, A. J., Carraway, M. S., and Madden, M. C. 2012. Composition of air pollution particles and oxidative stress in cells, tissues, and living systems. J. Toxicol. Environ. Health. B. 15: 1-21.

Giovannelli, L., Saieva, C., Masala, G., Testa, G., Salvini, S., Pitozzi, V., Riboli, E., Dolara, P., and Palli, D. 2002. Nutritional and lifestyle determinants of DNA oxidative damage: A study in a Mediterranean population. Carcinogenesis. 23: 1483-1489.

Hadžović-Džuvo, A., Valjevac, A., Lepara, O., Pjanić, S., Hadžimuratović, A., and Mekić, A. 2014. Oxidative stress status in elite athletes engaged in different sport disciplines. Bosnian. J. Basic. Med. Sci. 14: 56.

Heuser, V. D., Erdtmann, B., Kvitko, K., Rohr, P., and Da Silva, J. 2007. Evaluation of genetic damage in Brazilian footwear-workers: Biomarkers of exposure, effect, and susceptibility. Toxicology. 232: 235-247.

Hills, A. P., Dengel, D. R., and Lubans, D. R. 2015. Supporting public health priorities: Recommendations for physical education and physical activity promotion in schools. Prog. Cardiovasc. Dis. 57: 368-374.

Hincapie, C. A., Morton, E. J., and Cassidy, J. D. 2008. Musculoskeletal injuries and pain in dancers: A systematic review. Arch. Physical. Med. Rehabilitat. 89: 1819-1829.

INE (Statistics Portugal). 2015. Estatísticas Da Cultura 2015. Instituto Nacional De Estatística, I.P.. Lisboa, Portugal. ISSN 1647-4066/ISBN 978-989-25-0372-1.

Jonnalagadda, S. S., Skinner, R., and Moore, L. 2004. Overweight athlete: Fact or fiction?. Curr. Sports. Med. Rep. 3: 198-205.

Kasai, H., Iwamoto-Tanaka, N., Miyamoto, T., Kawanami, K., Kawanami, S., Kido, R., and Ikeda, M. 2001. Life style and urinary 8-hydroxydeoxyguanosine, a marker of oxidative DNA damage: Effects of exercise, working conditions, meat intake, body mass index, and smoking. Jap J. Cancer. Res. 92: 9-15.

Khan, K., Brown, J., Way, S., Vass, N., Crichton, K., Alexander, R., Baxter, A., Butler, M., and Wark, J. 1995. Overuse injuries in classical ballet. Sports. Med. 19: 341-357.

Koutedakis, Y. and Jamurtas, A. 2004. The dancer as a performing athlete. Sports. Med. 34: 651-661.

Kurkcu, R. 2010. The effects of short-term exercise on the parameters of oxidant and antioxidant system in handball players. Afr. J. Pharm. Pharmacol. 4: 448-452.

Kyparos, A., Vrabas, I. S., Nikolaidis, M. G., Riganas, C. S., and Kouretas, D. 2009. Increased oxidative stress blood markers in well-trained rowers following two thousandmeter rowing ergometer race. J. Strength. Conditioning. Res. 23: 1418-1426.

Marin, D. P., Bolin, A. P., Campoio, T. R., Guerra, B. A., and Otton, R. 2013. Oxidative stress and antioxidant status response of handball athletes: Implications for sport training monitoring. Int. Immunopharmacol. 17: 462-470.

Marin, D. P., Dos Santos, R. C., Bolin, A. P., Guerra, B. A., Hatanaka, E., and Otton, R. 2011. Cytokines and oxidative 
stress status following a handball game in elite male players. Oxidat. Med. Cell. Longevity. 2011: 804873.

Mihajlovic, B. and Mijatov, S. 2002. Body composition analysis in ballet dancers. Med. Pregl. 56: 579-583.

Möller, P. 2006. Assessment of reference values for DNA damage detected by the comet assay in human blood cell DNA. Mutat. Res. 612: 84-104.

Niess, A. M., Hartmann, A., Grunert-Fuchs, M., Poch, B., and Speit, G. 1996. DNA damage after exhaustive treadmill running in trained and untrained men. Int. J. Sports. Med. 17: 397-403.

Niess, A. M. and Simon, P. 2007. Response and adaptation of skeletal muscle to exercise-the role of reactive oxygen species. Front. Biosc. 12: 4826-4838.

Orhan, H., Van Holland, B., Krab, B., Moeken, J., Vermeulen, N. P., Hollander, P., and Meerman, J. H. 2004. Evaluation of multi-parameter biomarker set for oxidative damage in man: increased urinary excretion of lipid, protein and DNA oxidation products after one hour of exercise. Free. Rad. Res. 38: 1269-1279.

Powers, S. K. and Jackson, M. J. 2008. Exercise-induced oxidative stress: Cellular mechanisms and impact on muscle force production. Physiol. Rev. 88: 1243-1276.

Ribeiro, L. and Da Veiga, G. V. 2010. Risk behaviors for eating disorders in Brazilian dancers. Int. J. Sports. Med. 31: 283-288.

Rodrigues-Krause, J., Krause, M., Cunha Gdos, S., Perin, D., Martins, J. B., Alberton, C. L., Schaun, M. I., De Bittencourt, P. I., Jr., and Reischak-Oliveira, A. 2014. Ballet dancers cardiorespiratory, oxidative and muscle damage responses to classes and rehearsals. Eur. J. Sport. Sci. 14: 199-208.

Rowlands, D. S., Pearce, E., Aboud, A., Gillen, J. B., Gibala, M. J., Donato, S., Waddington, J. G. G., and Tarnopolsky, M. A. 2012. Oxidative stress, inflammation, and muscle soreness in an 894-km relay trail run. Eur. J. Appl. Physiol. 112: 1839-1848.

Russell, J. A. 2013. Preventing dance injuries: Current perspectives. Open. Access. J. Sports. Med. 4: 199-210.

Silva, J. R., Rebelo, A., Marques, F., Pereira, L., Seabra, A., Ascensão, A., and Magalhães, J. 2013. Biochemical impact of soccer: An analysis of hormonal, muscle damage, and redox markers during the season. Appl. Physiol. Nutr. Metab. 39: 432-438.

Singh, N. P., McCoy, M. T., Tice, R. R., and Schneider, E. L. 1988. A simple technique for quantitation of low levels of DNA damage in individual cells. Exp. Cell. Res. 175: 184-191.

Soares, J. P., Silva, A. M., Oliveira, M. M., Peixoto, F., Gaivão, I., and Mota, M. P. 2015. Effects of combined physical exercise training on DNA damage and repair capacity: Role of oxidative stress changes. Age. 37: 1-12.

Strassel, J. K., Cherkin, D. C., Steuten, L., Sherman, K. J., and Vrijhoef, H. J. 2011. A systematic review of the evidence for the effectiveness of dance therapy. Altern. Ther. Health. Med. 17: 50-59.

Trindade, C., Bortolini, G. V., Costa, B. S., Anghinoni, J. C., Guecheva, T. N., Arias, X., Césio, M. V., Heinzen, H., Moura, D. J., Saffi, J., Salvador, M., and Henriques, J. A. 2016. Antimutagenic and antioxidant properties of the aqueous extracts of organic and conventional grapevine Vitis labrusca cv. Isabella leaves in V79 cells. J. Toxicol. Environ. Health. Part A. 79: 825-836.

Wentzel, J. F., Gouws, C., Huysamen, C., Dyk, E., Koekemoer, G., and Pretorius, P. J. 2010. Assessing the DNA methylation status of single cells with the comet assay. Anal. Biochem. 400: 190-194.

Young, I. S. and McEneny, J. 2001. Lipoprotein oxidation and atherosclerosis. Biochem. Soc. Trans. 29: 358-362. 